\title{
Combined effects of adenovirus-mediated wild-type p53 transduction, temozolomide and poly (ADP-ribose) polymerase inhibitor in mismatch repair deficient and non-proliferating tumor cells
}

\author{
L Tentori ${ }^{1}$, I Portarena ${ }^{1}$, E Bonmassar ${ }^{1,2}$ and G Graziani ${ }^{\star, 1}$ \\ 1 Pharmacology and Medical Oncology Section, Department of Neuroscience, \\ University of Rome 'Tor Vergata', Via di Tor Vergata 135, 00133 Rome, Italy \\ 2 'Istituto Dermopatico dell'Immacolata' (IDI, IRCCS), Via dei Monti di Creta, \\ Rome, Italy \\ * Corresponding author: G Graziani, Department of Neuroscience, University of \\ Rome Tor Vergata, Via di Tor Vergata 135, 00133 Rome, Italy. \\ Tel: +39-0672596335/8; Fax: +39-0672596323; \\ E-mail: graziani@med.uniroma2.it
}

Received 16.5.00; revised 30.10.00; accepted 15.12.00

Edited by L Fesus

\begin{abstract}
Lack of p53 or mismatch repair (MR) function and scarce cell proliferation are commonly associated with tumor cell resistance to antineoplastic agents. Recently, inhibition of poly(ADP-ribose) polymerase (PARP) has been considered as a tool to overcome resistance of MR-deficient tumors to methylating agents. In the present study we demonstrated that infection with p53 expressing adenovirus (Ad-p53), enhances chemosensitivity of MR-deficient tumor cell lines to the methylating agent temozolomide (TZM), either used as single agent or, more efficiently, when combined with PARP inhibitor. Moreover, the association of Ad-p53 with drug treatment induced a more pronounced growth inhibitory effect than that provoked by Ad-p53 infection only. Cells, growth arrested by $p 53$ transduction, and then subsequently exposed to the drugs, were still highly susceptible to cytotoxicity induced by TZM and PARP inhibitor. The results suggested that this drug combination might be effective even in nonproliferating tumor cells. It is conceivable to envisage future possible strategies to enhance cytostatic or cytotoxic effects induced by Ad-p53, based on the use of TZM, alone or combined with PARP inhibitor for the therapy of resistant tumors. Cell Death and Differentiation (2001) 8, 457-469.
\end{abstract}

Keywords: DNA repair; chemotherapy; methylating agents; drug resistance

Abbreviations: MR, mismatch repair; BER, base excision repair; TZM, temozolomide; PARP, poly(ADP-ribose) polymerase; Ad, adenovirus; $\mathrm{MOI}$, multiplicity of infection; beta-Gal, beta-galactosidase; 3-AB, 3-aminobenzamide; 5-BrdU, 5-bromodeoxyuridine; $\mathrm{TS}$, thymidylate synthase; $5-\mathrm{FU}, 5$-fluorouracil; raltitrexed, $N-[5-[\mathrm{N}-$ (3,4-dihydro-2-methyl-4-oxoquinazolin-6-ylmethyl)- $N$-methylamino]-2-thenoyl]-L-glutamic acid; O.D., optical densities; PI, propidium iodide

\section{Introduction}

A number of studies demonstrated that the p53 tumor suppressor gene plays a major role in apoptosis/growth arrest or DNA repair, in response to DNA damage, including that deriving from chemotherapeutic agents. ${ }^{1-4}$ Actually, genetic abnormalities resulting in loss of p53 function can contribute to the frequent clinical resistance of solid tumors to chemotherapeutic treatments. In addition, it has been observed that wild-type p53 overexpression in cancer cells can directly induce cells to undergo apoptosis and/or growth arrest. $^{5-9}$ These findings provided the rational basis for gene transfer based techniques aimed at restoring or enhancing the wild-type p53 function, thus providing additional devices for cancer control.

Mutation of the p53 gene is the most common genetic alteration $^{10}$ detected in human solid tumors (e.g. $70 \%$ in colorectal cancers). ${ }^{11}$ Moreover, although mutations in the p53 tumor suppressor gene are not common in hematological malignancies, they have been frequently detected in therapy-related acute myeloid leukemias (i.e. 39\%). ${ }^{12,13}$ In any case, p53 mutations are associated with low complete remission rate, early relapse and poor survival. ${ }^{14,15}$

Genetic abnormalities responsible for drug resistance also involve genes encoding for components of the DNA mismatch repair (MR), which plays an important role in maintaining genomic stability. ${ }^{16}$ Defects in MR function result in tumor cell resistance to $\mathrm{O}^{6}$-methylating compounds and to a number of antineoplastic agents with different mechanisms of action, such as 6-thioguanine, cisplatin and doxorubicin. ${ }^{17}$

A functional MR is required for the triggering of the apoptotic process in response to $0^{6}$-methylguanine DNA adducts. ${ }^{18}$ In contrast, tumor cell susceptibility to damage derived from methyl adducts generated at DNA sites different from $\mathrm{O}^{6}$-guanine does not require the presence of a functional MR. ${ }^{19,20}$ However, these DNA adducts are efficiently removed by the base excision repair (BER) and include $\mathrm{N}^{3}$-methyladenine, that is generated at low levels in the DNA by the methylating agents commonly used in the clinic, such as dacarbazine or temozolomide (TZM). ${ }^{21}$ Therefore, in the presence of a functional BER, this damaged base is promptly repaired.

It was previously demonstrated that pharmacological strategies to overcome resistance of MR-deficient tumor cells to $\mathrm{O}^{6}$-methylating agents might rely on the inhibition of poly(ADP-ribose) polymerase (PARP). ${ }^{19,20,22,23}$ This enzyme is a component of the BER multiprotein complex and is required in sensing and signaling of DNA damage generated by monofunctional alkylating agents. ${ }^{24}$ The 
inhibition of PARP is likely to hamper the completion of the BER-mediated repair process, which occurs after the methylated base has been removed by the 3-methylpurine glycosylase.

The killing effect, deriving from interruption of BERmediated repair process of $\mathrm{N}$-methylpurines, is already evident during the first round of cell division. ${ }^{20}$ In contrast, cytotoxicity induced by MR-mediated processing of $\mathrm{O}^{6}$ methylguanine occurs during the second cycle of DNA replication. ${ }^{18}$ These observations suggested that the drug combination of a methylating agent with a PARP inhibitor might be also useful for tumors with low proliferation rate. At this regard, it has to be noted that the poor response of solid tumors to chemotherapy is often related to the scarce proliferation of the majority of cells. In fact, cells in the $G_{0} /$ $\mathrm{G}_{1}$ phase of the cell cycle are usually resistant to antineoplastic agents that require DNA synthesis to provoke DNA damage.

The aim of the present study is to investigate whether transduction of wild-type p53, mediated by adenovirus vector (Ad-p53), might increase susceptibility of MRdeficient tumor cells to TZM, alone or combined with PARP inhibitor. Moreover, it was also explored whether neoplastic cells, subjected to growth arrest by p53 transduction, might be still susceptible to the cytotoxic effects of the methylating agent.

The results provided evidence for the first time that Adp53 strongly enhanced the susceptibility of MR-deficient tumor cell lines, to TZM, alone or combined with PARP inhibitor. Moreover, the results indicated that TZM associated with a PARP inhibitor was markedly cytotoxic even in tumor cells that, after Ad-p53 infection, failed to proliferate.

\section{Results}

\section{Adenovirus-mediated p53 expression in p53-null leukemic Jurkat cells increases cytotoxicity induced by TZM, alone or combined with PARP inhibitor}

p53-null leukemic Jurkat cells were transduced in vitro with Ad-p53 at a multiplicity of infection (MOI) of 80 . The expression of p53 and growth kinetics of control or Ad-p53 infected cells were evaluated. The results of Western blot analysis, illustrated in Figure $1 \mathrm{~A}$, show that p53 protein could be detected only in Ad-p53 infected cells 1 day after infection. Wild-type $\mathrm{p} 53$ expression reached the peak 2 days after virus exposure and then gradually declined. Cell growth analysis showed a significant reduction in the growth rate of Ad-p53 infected cells with respect to controls ( $P<0.01$; Figure 1B). No significant differences in cell growth kinetics were found between uninfected or Ad-beta-galactosidase (Ad-beta-Gal) infected control cells (Figure 1B).

Morphological and flow cytometry analysis of apoptosis in Ad-p53 infected cells evidenced only a limited percentage of cells undergoing apoptosis at all time points $(<7 \%)$, comparable to that detected in controls.

Control Ad-beta-Gal or Ad-p53 infected cells were treated with TZM, alone or combined with the PARP
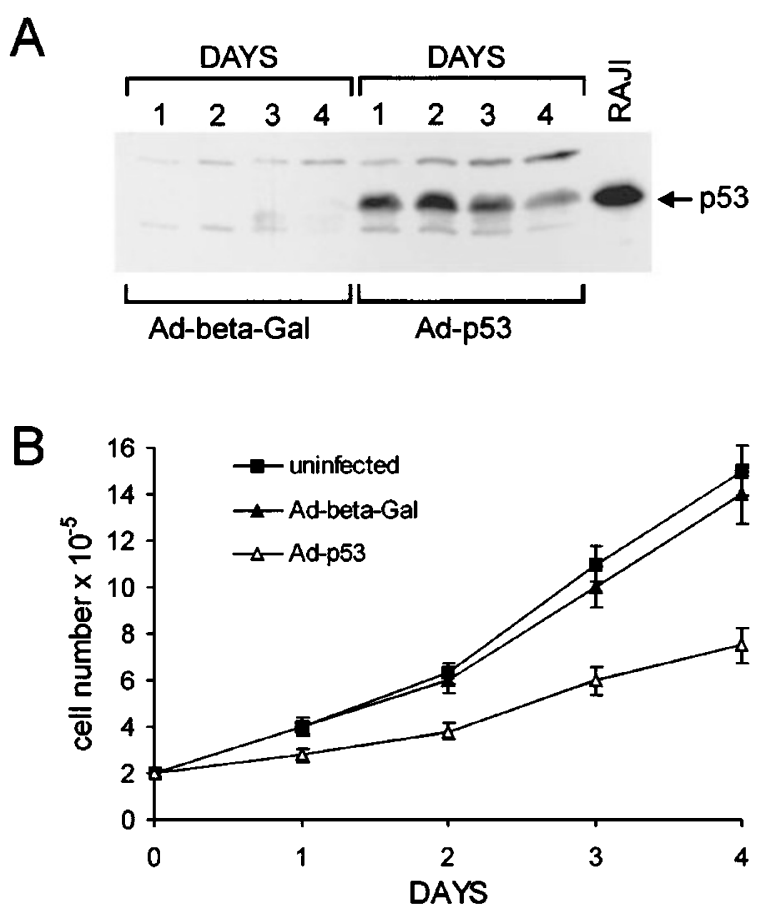

Figure 1 Expression of $p 53$ and cell growth analysis in Ad infected Jurkat cell line. Cells were infected with Ad-beta-Gal or Ad-p53 (80 MOI) and p53 protein expression (A) or cell proliferation (B) were evaluated 1-4 days after $\mathrm{Ad}$ exposure. (A) Immunoblot analysis of p53 expression in Ad-beta-Gal and Adp53 cells. Raji cells, which express a mutated form of p53, were used as positive control. Equal loading of proteins was checked by red S Ponceau staining (data not shown). The results of densitometric analysis (O.D.) of the p53 protein were as follows: day 1, O.D.: 3.8; day 2, O.D.: 4.1; day 3, O.D.: 3.3; day 4, O.D.: 2.1; Raji, O.D.: 4.3. (B) Growth kinetics of uninfected, Ad-beta-Gal and Ad-p53 cells. Cell growth was evaluated in terms of number of viable cells by using trypan blue exclusion test. Each value represents the mean of cell counts performed in quadruplicate. Bars: S.E. of the mean. The differences between Ad-p53 and both controls were statistically significant at all time points $(P<0.01)$. The results are representative of one out of three repeated experiments

inhibitor 3-aminobenzamide (3-AB), 1 day after virus exposure. The kinetics of appearance and the extent of growth inhibition induced by the drugs are illustrated in Figure 2. Treatment with the methylating agent showed marginal or no antitumor activity against Ad-beta-Gal infected Jurkat cells (Figure 2A). In contrast, TZM (125 and $250 \mu \mathrm{M})$ significantly reduced the growth of p53 expressing cells after 3 and 4 days of culture $(P<0.01$; Figure 2B). Combined treatment with $T Z M+3-A B$ significantly inhibited cell proliferation of Ad-beta-Gal cells at 125 or $250 \mu \mathrm{M}$ TZM $(P<0.01$; Figure 2C). However, drugtreated cells retained proliferative potential, since cultures subjected to $\mathrm{TZM}+3-\mathrm{AB}$ started again to proliferate 2-3 days after drug exposure (Figure 2C). In p53 transduced cells the PARP inhibitor augmented the cytotoxicity afforded by TZM used as a single agent $(P<0.01$; Figure $2 \mathrm{D})$. In this case, however, p53 expressing cells were unable to recover the damage induced by the drug combination, at least at the two highest TZM concentrations (Figure 2D). In all experimental conditions, 3-AB alone was found to be essentially inactive against Jurkat cells (Figure 2). 

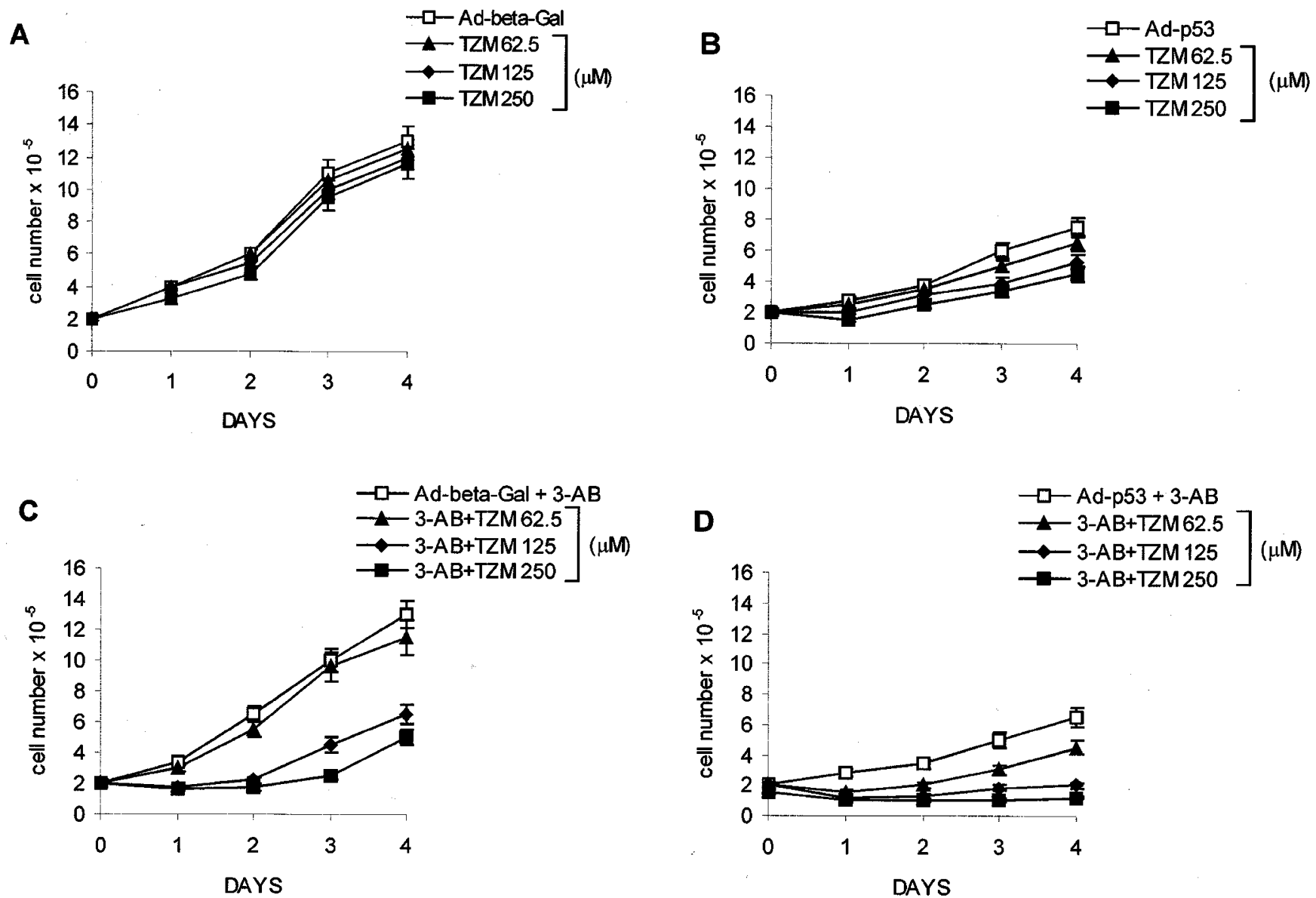

Figure 2 Cell growth analysis of Jurkat cells treated with TZM, as a single agent $(\mathbf{A}, \mathbf{B})$ or combined with 3-AB (C, D), after infection with either Ad-beta-Gal (A, C) or Ad-p53 (B, D). The results are representative of one out of three repeated experiments. Statistical analysis was performed as described in legend to Figure 1. Statistically significant differences between groups are reported in the Results section

Flow cytometry analysis of sub-diploid DNA content (Figure 3A,B) indicated that p53 expression markedly potentiated the apoptotic effect of TZM+3-AB combination.

The expression of p53 was investigated in drug-treated cells 1 day after drug exposure (i.e. 2 days after $\mathrm{Ad}$ infection). Western blot analysis showed no substantial differences in p53 expression between untreated or drug treated groups (Figure $3 \mathrm{C}$ ).

To examine whether Ad infection and/or drug treatment might trigger p21 induction, we determined p21 protein levels by Western blotting in untreated and drug treated Ad infected cells. The results, illustrated in Figure 3C, show a slight induction of p21 in Ad-p53 cells 1 day after infection, that paralleled the expression of the p53 protein. The level of p21 protein increased in response to p53 transduction after 2 days in either treated or untreated groups. It should be noted that at this time point the level of p21 expression in cells exposed to $250 \mu \mathrm{M}$ TZM+3-AB was twofold higher than that of $3-A B$ treated control. No induction of p21 protein was detected in Ad-beta-Gal infected cells (Figure 3C).

Next, we investigated whether Ad-p53 infection, alone or combined with drug treatment, was associated with changes in the cell distribution through the different phases of cell cycle. Flow cytometry analysis showed that Ad-p53 infected samples did not show any substantial difference in the cell cycle distribution with respect to beta-Gal or uninfected controls (data not shown). In contrast, in Adp53 infected cells the association of 3-AB and $250 \mu \mathrm{M}$ TZM induced a progressive increase of cells in the $G_{1}$ phase, after 3 days of culture $(2-3$-fold increase with respect to day 1). Conversely, combined treatment with $T Z M+3-A B$ in Ad-beta-Gal infected cells resulted in cell accumulation in the $G_{2} / M$ phase (percentage of cells in $G_{2} / M$ phase: $40 \pm 9$ at $250 \mu \mathrm{M}$; untreated or $3-\mathrm{AB}$ treated controls; $7 \pm 2$, at day 2). However, this cell cycle modification was transient, since after 3 days of culture, cells recycled back into $G_{1}$.

In both Ad-beta-Gal and Ad-p53 infected cells, treatment with TZM did not induce any substantial change of cell cycle profiles with respect to untreated controls (data not shown).

\section{Adenovirus-mediated p53 expression in colon carcinoma HCT-15 cells, that express a mutated form of p53, increases cytotoxicity induced by TZM, alone or combined with PARP inhibitor}

The influence of p53 expression on cell growth and chemosensitivity to TZM, alone or in the presence of PARP 
A

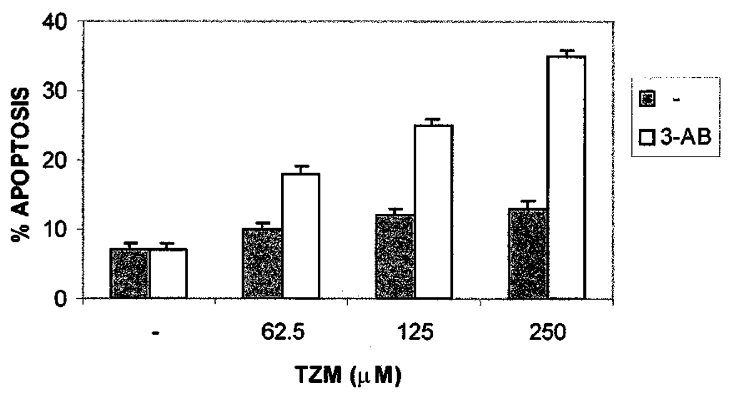

B

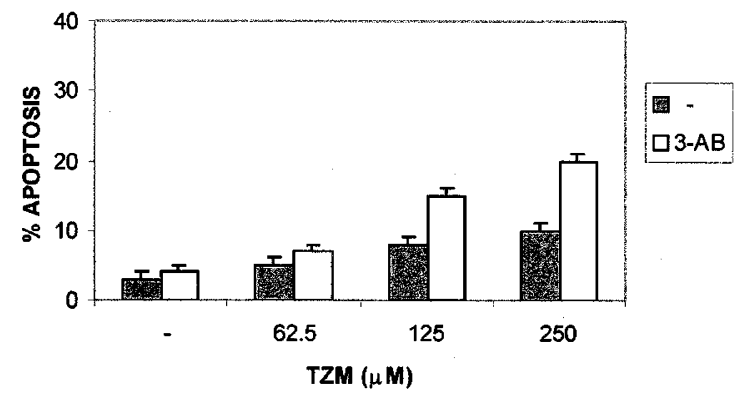

C

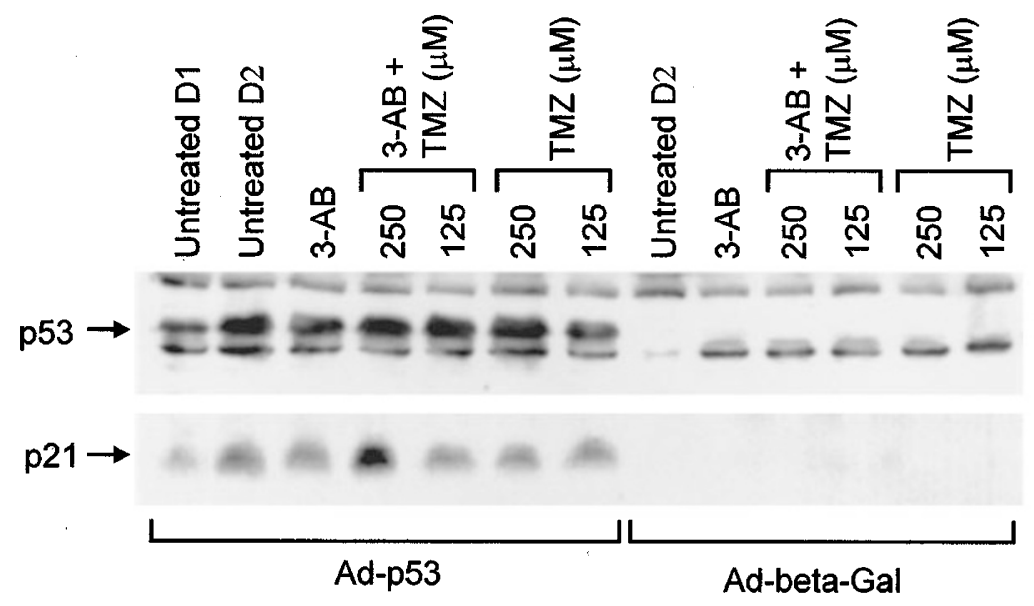

Figure 3 Analysis of apoptosis, p53 and p21 expression in Ad infected and drug treated Jurkat cells. Apoptosis induction in Ad-p53 (A) and Ad-beta-Gal (B) cells exposed to TZM, alone or combined with 3-AB. Histograms represent the mean of the percentages of apoptotic cells evaluated by flow cytometry analysis of DNA content. Data represent the results obtained in three independent experiments. Bars: S.E. of the mean. Western blot analysis (C) of p53 or p21 in untreated or drug treated Ad-p53 and Ad-beta-Gal cells. In untreated cells, immunoblot analysis was performed at day 1 and 2 (D1 and D2) after infection. As regard to drug treated cells, p53 and p21 expression was evaluated 2 days after infection (i.e., 1 day after drug exposure). The results are representative of one out of two different experiments

inhibitor, was further studied in a model of solid tumor, represented by a human colon carcinoma cell line. At this point, MR-deficient HCT-15 cells, which express a mutated form of p53, were transduced in vitro with Ad-p53 at a $\mathrm{MOI}$ of 2.5 or 80 . Cell growth kinetics of control Ad-beta-Gal or Adp53 infected cells at a $\mathrm{MOI}$ of 80 , revealed an initial reduction of cells 1 day after virus exposure. Thereafter, the cell number showed no further change (Figure 4A).

Expression of p53 on day 1 post-infection, in HCT-15 cells was higher in cells infected at a $\mathrm{MOI}$ of 80 as compared to control cells endowed with a mutated form of p53 (Figure 4B). When HCT-15 cells were transduced at a $\mathrm{MOI}$ of 2.5 , a less pronounced increase in wild-type p53 levels could be detected (Figure 4B). In spite of the limited p53 expression, the growth rate of Ad-p53 infected cells was markedly reduced with respect to that of beta-Gal control (Figure 4A). Ad-p53 infection at MOI of 5 and 10 induced a growth inhibition similar to that provoked by infection at a $\mathrm{MOI}$ of 2.5, whereas infection at a $\mathrm{MOI}$ of 40 was slightly less cytotoxic than $80 \mathrm{MOI}$ (data not shown).

On the basis of these results, to investigate the influence of p53 expression on sensitivity of HCT-15 cells to cytotoxicity induced by the agents under study, Ad infection was performed at MOls of 2.5 and 80 , which markedly differed in their effects on cell growth. Ad-betaGal or Ad-p53 infected cells were treated with the drugs, 1 day after virus exposure (Figure 5). Drug treatment of HCT15 cells infected with Ad-p53 at a MOI of either 2.5 or 80 , resulted in a pronounced reduction of the cell number, either when TZM was used as single agent or when it was combined with 3-AB (Figure 5B,C). Moreover, Ad-p53 cells, infected at a $\mathrm{MOI}$ of 80 , and then exposed to TZM, alone or associated with $3-\mathrm{AB}$, were no longer able to proliferate during the 4 days of culture (data not shown). In contrast, in Ad-beta-Gal infected cells, only $\mathrm{TZM}+3-\mathrm{AB}$ combination significantly affected cell proliferation $(P<0.01)$, even though at a lower extent than in Ad-p53 infected cells (Figure 5A). However, in this case drug-treated cells retained proliferative potential, since cultures started again to proliferate 2 days after drug exposure (data not shown).

A limited induction of apoptosis was observed in Ad-p53 infected cells treated with $125 \mu \mathrm{M}$ and $250 \mu \mathrm{M}$ TZM, alone $(10 \pm 2$ and $12 \pm 3 \%$, respectively) or combined with PARP inhibitor (15 \pm 3 and $19 \pm 3 \%$, respectively). In contrast, no apoptosis was observed in Ad-beta-Gal cells exposed to the same concentrations of the agents $(<5 \%)$. 
A

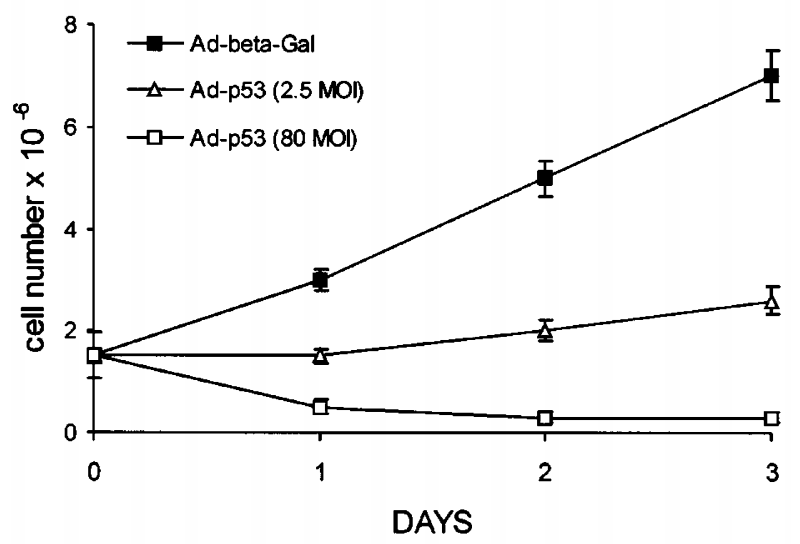

B

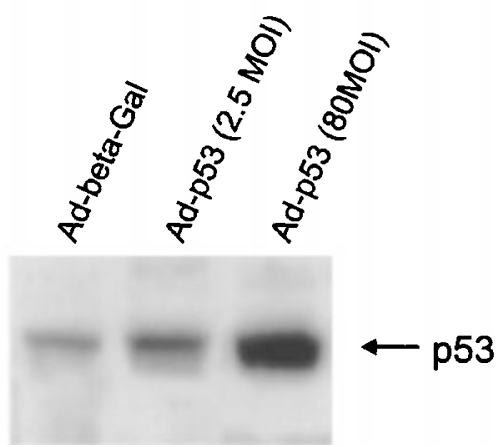

Figure 4 Cell growth analysis and p53 expression in Ad infected HCT-15 cell line. Cells were infected with Ad-beta-Gal or Ad-p53 (2.5 or $80 \mathrm{MOI}$ ) and cell proliferation (A) or p53 protein expression (B) were evaluated. (A) Growth kinetics of Ad-beta-Gal and Ad-p53 cells. Cell proliferation was evaluated as described in legend to Figure 1. The differences between cells exposed to Adp53 (either at 2.5 or $80 \mathrm{MOI}$ ) and Ad-beta-Gal control were statistically significant at all time points $(P<0.01)$. The results are representative of one out of three repeated experiments. (B) Immunoblot analysis of p53 expression in Ad-beta-Gal and Ad-p53 cells. The expression of p53 was evaluated 1 day after infection. Equal loading of proteins was checked by red S Ponceau staining (data not shown). The results are representative of one out of two different experiments

Analysis of the expression of p53 and p21 proteins in Ad infected cells, either untreated or drug treated, is illustrated in Figure 6A,B. High amounts of either p53 or p21 could be detected in all Ad-p53 samples, whereas in control HCT-15 cells the monoclonal antibody used allowed immunodetection of the mutated form of the p53 protein.

Cell cycle distribution of Ad infected, untreated or drug treated cells were analyzed 1 day after drug exposure. Figure 6C shows that Ad-p53 infection induced an accumulation of the cells in the $G_{1}$ phase and a concomitant reduction of cells in S-phase. This distribution through the different phases of the cell cycle was not substantially influenced by the drug treatment (Figure 6C). Moreover, cells remained arrested at the $\mathrm{G}_{1}$ phase during the following 3 days of culture (data not shown). In contrast, Ad-beta-Gal infected cells exposed to the combined treatment of TZM and $3-A B$ accumulated in the $G_{2} / M$ phase.
A

Ad-beta-Gal

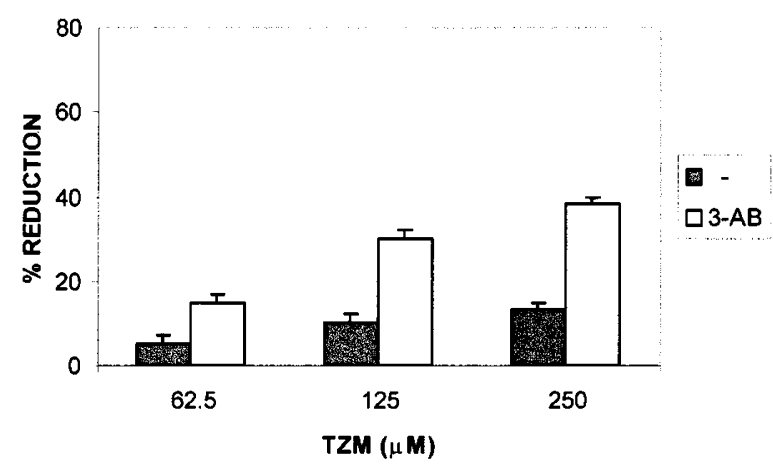

B

Ad-p53 (2.5 MOI)

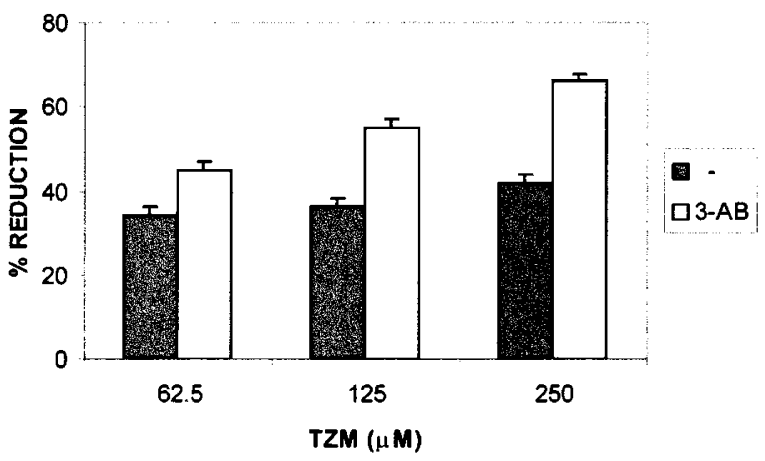

C

Ad-p53 (80 MOl)

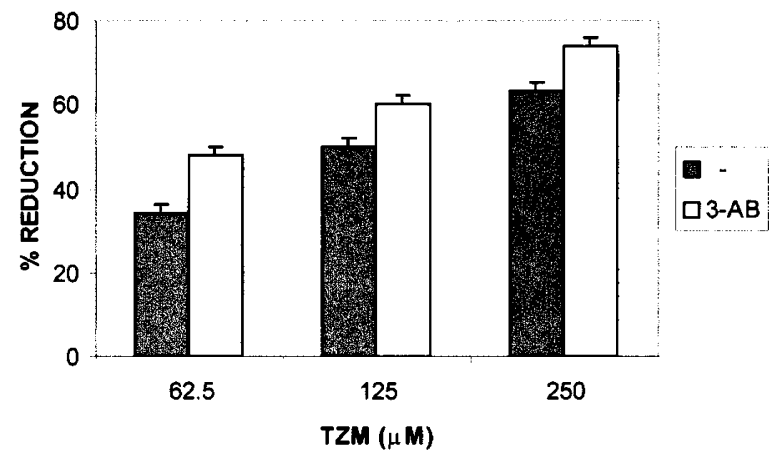

Figure 5 Reduction of cell number induced by $T Z M \pm 3-A B$ in $A d$-beta-Gal and Ad-p53 HCT-15 cells. Cells were infected with Ad-beta-Gal (A) or Ad-p53 at a $\mathrm{MOI}$ of 2.5 (B) or 80 (C). After $24 \mathrm{~h}$ infected cells were treated with $\mathrm{TZM} \pm 3-\mathrm{AB}$ and counted 1 day after drug exposure. Histograms represent the mean of the percentage reduction of cell number with respect to untreated or 3-AB treated controls. Bars: S.E. of the mean. The results are representative of one out of three independent experiments

\section{Subcellular localization of adenovirus-mediated p53 expression}

In order to test whether the different effect exerted by Adp53 on cell growth of Jurkat and HCT-15 cells might be due to a distinct subcellular distribution of transduced p53, expression of the protein was assessed either in the nuclear 
A

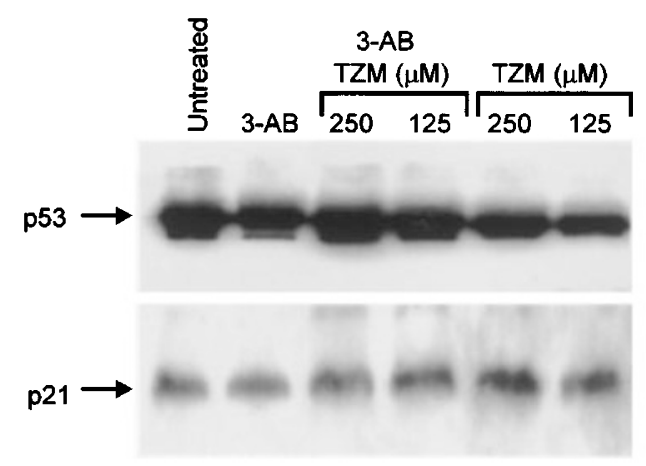

C

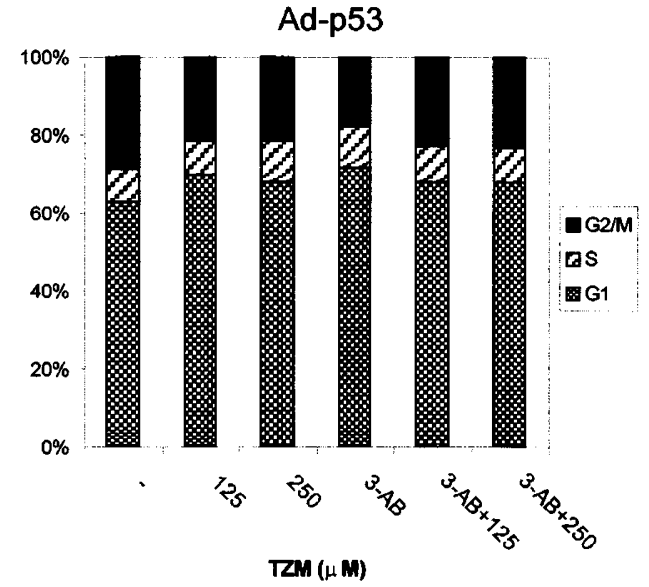

B

Ad-beta-Gal

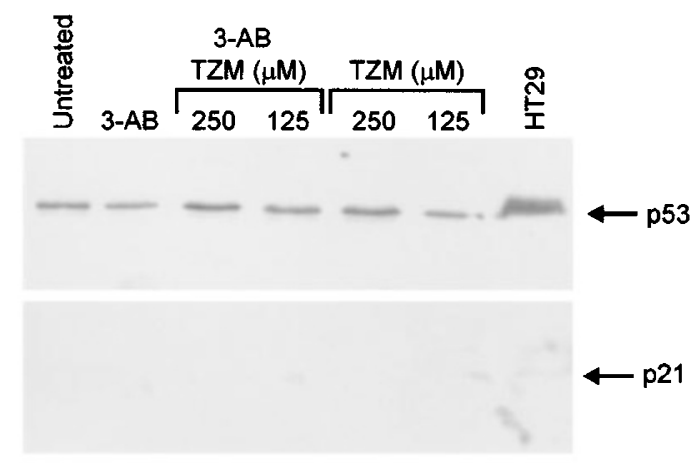

D

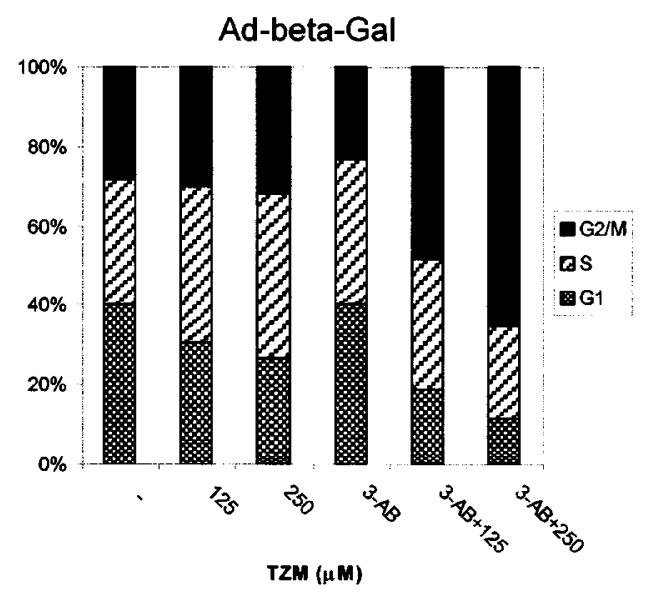

Figure 6 Analysis of p53 and p21 expression and cell cycle in Ad infected and drug treated HCT-15 cells. Western blot analysis of either p53 or p21 in untreated or drug treated Ad-p53 (A) and Ad-beta-Gal (B) cells. Immunoblot analysis was performed 2 days after infection (i.e., 1 day after drug exposure). Colon carcinoma HT29 cells, which express a mutated form of p53, were used as positive control. Equal loading of proteins was checked by red S Ponceau staining (data not shown). The results are representative of one out of three different experiments. Differences among samples in the O.D. values relative to p53 or p21 expression never exceeded 30\%. Cell cycle perturbation induced by p53 overexpression and/or drug treatment in HCT-15 cells. The percentage of Ad-p53 (C) or Ad-beta-Gal (D) cells in each phase of cell cycle was evaluated by flow cytometry analysis of DNA content. Data represent the mean of three independent experiments with S.E. never exceeding $5 \%$

or cytoplasmic fraction of infected cells. The results of Western blot analysis (Figure 7A), performed using an equal number of cells, indicated that: (a) in Ad-p53 infected Jurkat cells, p53 expression was detectable only in the cytoplasm; (b) in HCT-15 cells, p53 was overexpressed both in the cytoplasmic and nuclear compartments; (c) the level of p53 protein present in Jurkat cells was lower than that detected in HCT-15 cells; (d) no p53 expression was detected in control Jurkat cells, whereas the mutated protein was observed in control HCT-15 cells; (e) in both cell lines actin expression was found only in the cytoplasmic fraction.

Western blot analysis was then performed using an amount of nuclear proteins 10 -fold higher than that tested in the immunoblot shown in Figure 7A. In this experimental condition, p53 could be detected also in the nuclear fraction of Ad-p53 infected Jurkat cells (Figure 7B).
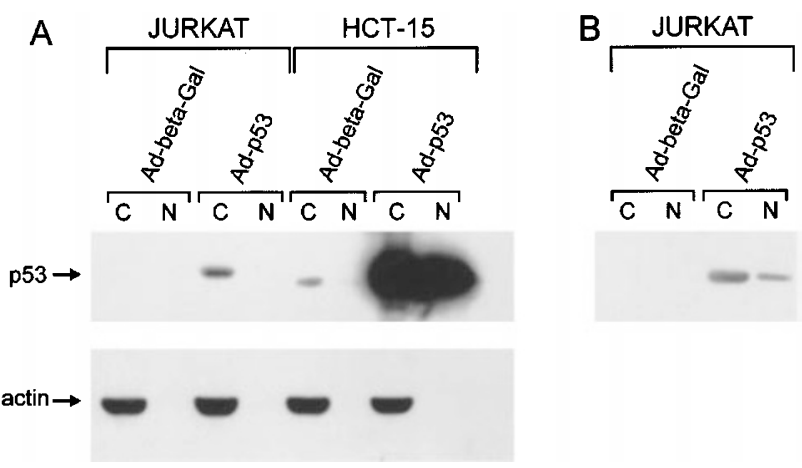

Figure 7 Subcellular localization of p53 expression in Ad infected Jurkat or HCT-15 cells. (A) Western blot analysis of cytoplasmic (C) or nuclear fraction (N) corresponding to equal number of cells $\left(1 \times 10^{6}\right)$. The amount of loaded proteins was: Jurkat (C) $80 \mu \mathrm{g}$, (N) $9 \mu \mathrm{g}$; HCT-15 (C) $40 \mu \mathrm{g}$. (N) $9 \mu \mathrm{g}$. Protein loading was checked by red S Ponceau staining (data not shown) (B) Western blot analysis of equal amount of proteins $(90 \mu \mathrm{g})$, corresponding to cytoplasmic $(\mathrm{C})$ or nuclear fraction $(\mathrm{N})$ of Ad infected Jurkat cells 


\section{Cytotoxicity of TZM combined with the PARP inhibitor occurs also in cells that do not actively synthesize DNA}

In order to test whether cells arrested in their growth are still susceptible to the cytotoxicity induced by the combination of TZM and PARP inhibitor, HCT-15 cells were exposed to the drugs 2 days after infection at a $\mathrm{MOI}$ of 20 . In fact, in this experimental condition cells were no longer able to proliferate, although no reduction in cell number was observed (Figure $8 \mathrm{~A})$. It was then investigated whether any DNA synthesis could be detected in Ad-p53 infected HCT-15 cells at the moment of drug exposure, by means of 5-bromodeoxyuridine (5-BrdU) incorporation. The results of a representative experiment are illustrated in Figure $8 \mathrm{~B}$ and show that a limited percentage of cells in the S-phase was observed 1 day after infection, whereas most of the cells accumulated in $\mathrm{G}_{1}$ phase. Moreover, on day 2 post-infection virtually no incorporation of 5-BrdU was detected. In addition, in Ad-p53 infected cells a marked and progressive induction of p21 was observed (Figure 8C). Altogether, these data indicated that the growth of HCT-15 cells was completely arrested 2 days after exposure to Ad-p53 at a MOI of 20.

Cells were then exposed to $250 \mu \mathrm{M}$ TZM, alone or in combination with $3-\mathrm{AB}$, and analyzed for cell number 1 day after treatment. The results are expressed as percentage of cell number reduction of drug treated cells with respect to untreated controls. Two antitumor agents, that are used for treatment of colon carcinoma, were also tested. In particular, raltitrexed, a direct inhibitor of thymidylate synthase (TS) was used as a control of an anticancer agent that requires active DNA synthesis in order to be effective. Moreover, 5-fluorouracil (5-FU), which indirectly inhibits TS but also affects RNA function, was tested. The results, illustrated in Figure 9, show that TZM combined with the PARP inhibitor markedly reduce the number of Adp53 cells. In contrast, raltitrexed $(100 \mathrm{nM})$ induced a reduction of cell growth only in Ad-beta-Gal controls, whereas it did not have any effect in Ad-p53 cells. On the other hand, induction of wild-type p53 potentiated the cytotoxicity of 5-FU (10 $\mu \mathrm{M})$ (Figure 9).

\section{Adenovirus-mediated p53 expression in tumor cells bearing wild-type p53 gene, increases cytotoxicity induced by TZM, alone or combined with PARP inhibitor}

Leukemic MT-1 or colon carcinoma HCT-116 cells, that possess wild-type p53 gene and a functional defect in MR function, were transduced in vitro with Ad-p53 at a $\mathrm{MOI}$ of 80 . The kinetics of p53 expression during 3 days of culture was evaluated. The results of Western blot analysis, illustrated in Figure 10, show that p53 protein could be detected only in Adp53 infected cells. In MT-1 cells the level of p53 expression reached the peak 1 day after virus exposure and thereafter declined, unlike in HCT-116 where the transduced protein was overexpressed at all time points tested.

Cell growth analysis in MT-1 cells showed a significant reduction in the growth rate of Ad-p53 infected cells with respect to controls $(P<0.01$, Figure 11). Treatment with the
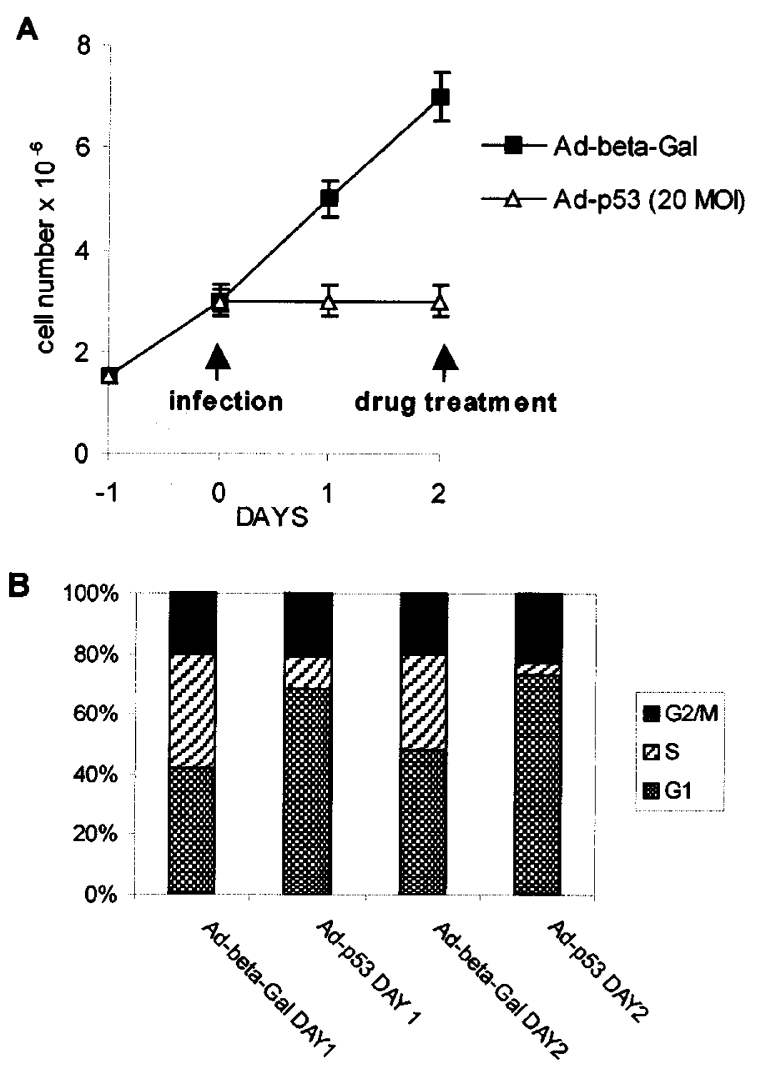

C

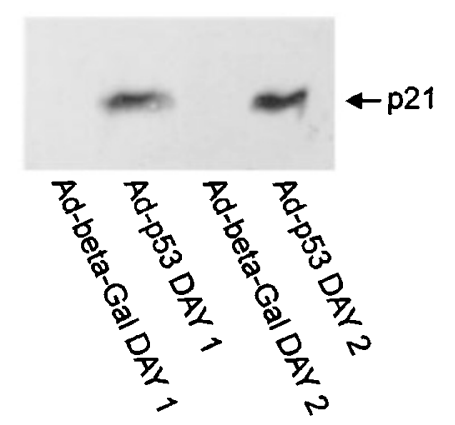

Figure 8 Cell growth, cell cycle and p21 expression in HCT-15 cells infected at a $\mathrm{MOI}$ of 20. (A) Cell growth analysis of cells infected with Ad-p53 or Adbeta-Gal. Arrows point the day of infection or drug treatment. (B) Time course analysis of cell cycle in cells infected with Ad-p53 or Ad-beta-Gal. Cells were cultured after virus exposure and processed for cell cycle analysis at day 1 and 2. 5-BrdU was added to the culture $1 \mathrm{~h}$ before harvesting. The percentage of cells in each phase of cell cycle was evaluated by flow cytometry analysis of 5BrdU incorporation and DNA content. The results are representative of one out of two different experiments. (C) Western blot analysis of p21 expression in Ad infected cells. Equal loading of proteins was checked by red S Ponceau staining (data not shown)

methylating agent induced limited cytotoxic activity against Ad-beat-Gal infected MT-1 cells (Figure 11A). In contrast, TZM (125 and $250 \mu \mathrm{M})$ significantly reduced the growth of Ad-p53 infected cells after 3 and 4 days of culture $(P<0.01$; Figure 11B). Treatment of Ad-beta-Gal cells with $3-\mathrm{AB}$ significantly $(P<0.01)$ increased cytotoxicity 


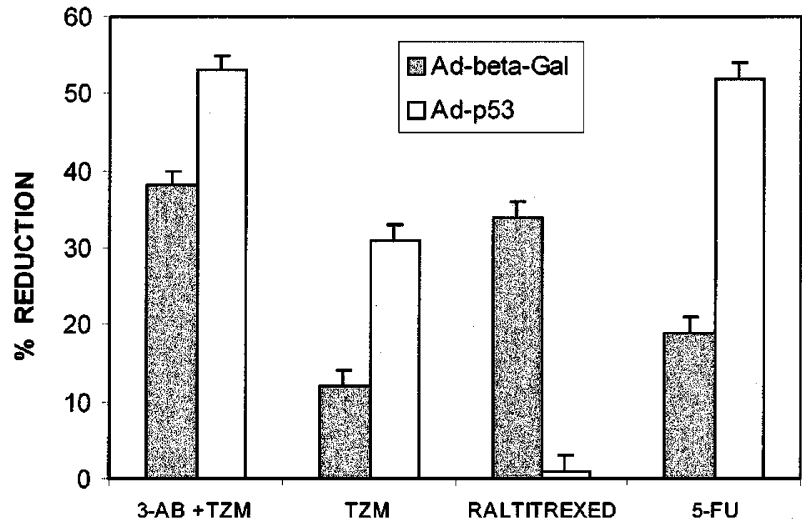

Figure 9 Comparison between the cytotoxicity induced by TZM, alone or combined with PARP inhibitor, and that provoked by raltitrexed or by $5-\mathrm{FU}$, in Ad-p53 infected HCT-15 cells in the absence of active DNA synthesis. Histograms represent the mean of the percentages of cell reduction with respect to controls. Data represent the mean values of three independent experiments Bars: S.E. of the mean

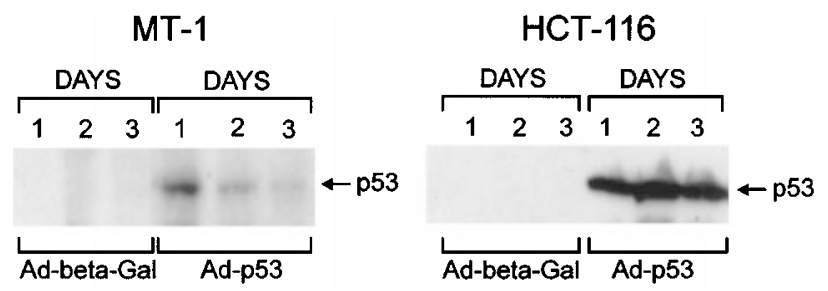

Figure 10 Expression of p53 in Ad infected MT-1 and HCT-116 cells. MT-1 or HCT-116 cells were infected with Ad-beta-Gal or Ad-p53 (80 MOI) and immunoblot analysis of p53 expression was performed 1-3 days after Ad exposure. Equal loading of proteins was checked by red S Ponceau staining (data not shown)

induced by TZM. However, drug-treated cells retained proliferative potential (Figure 11C). In contrast, p53 expressing cells were unable to recover the damage induced by the drug combination, at least at the two highest TZM concentrations (Figure 11D).

Flow cytometry analysis of sub-diploid DNA content in Ad-p53 infected cells evidenced only a limited percentage of cells undergoing apoptosis at all time points $(<4 \%)$, comparable to that detected in controls. Moreover, p53 transduction significantly $(P<0.01)$ potentiated the apoptotic effect of TZM+3-AB combination (data not shown).

Ad-p53 infection of HCT-116 resulted in growth arrest. Nonetheless, Ad-p53 infected cells were susceptible to cytotoxicity induced by TZM, either used as single agent or combined with 3-AB (Figure 12). Noteworthy, the combination of Ad-p53 infection and chemotherapy was more cytotoxic with respect to pharmacological treatment $(P<0.01)$. In Ad-beta-Gal infected cells, although 3-AB potentiated the antitumor effect of TZM, growth inhibition was only transient (Figure 12).

In the case of HCT-116, p53 overexpression significantly potentiated (2-3-fold increase) the apoptotic effect of either TZM or TZM+3-AB combination.

\section{Discussion}

Lack of p53 and MR function and scarce tumor cell proliferation are generally associated with tumor cell phenotype of resistance to antineoplastic agents. In the present study we demonstrated, for the first time, that wildtype p53 transduction enhances chemosensitivity of MRdeficient tumor cells to the methylating compound TZM, either used as single agent or combined with PARP inhibitor. Moreover, it was pointed out that this drug combination is also highly cytotoxic in the absence of active DNA synthesis and regardless of the cellular p53 status.

In the model system that we used, Ad-p53 infection of leukemic cells was associated with a transient growth inhibitory effect. Unlikely, p53 overexpression in colon carcinoma cells completely suppressed cell growth. In the cell lines tested, however, Ad-p53 infection did not induce apoptosis. These data are in accordance with previous studies with different tumors, including colon carcinoma. ${ }^{25-27}$ Nevertheless, other reports showed that overexpression of wild-type p53 induced apoptosis. ${ }^{28-30}$ Overall, these results suggested that a variety of tumor types might present different responses to high levels of p53 expression. Moreover, in the case of leukemic cells, it cannot be excluded that upon Ad infection not all the cells were infected by the virus or adequately expressed the transgene, since leukemic cells have been described to be quite resistant to Ad infection. ${ }^{31,32}$ Actually, in Jurkat cells, most of the ectopic p53 protein was confined in the cytoplasmic compartment, whereas in HCT-15 cells a high level of the transduced protein was observed also in the nuclei.

In tumor cell lines p53 expression was accompanied by transactivation of $p 21$, which is known to mediate $G_{1}$ cell cycle arrest by causing inhibition of the cyclin-dependent kinase activity required for the progression from the $G_{1}$ to the S-phase. ${ }^{33,34}$ Nonetheless, Ad-p53 infection induced a marked $\mathrm{G}_{1}$ and growth arrest only in colon carcinoma cells.

Taking into account the possible limitations of Ad-p53 infection, it was of interest to investigate whether the combination of gene therapy based on p53 transduction with chemotherapy might result in enhanced cytotoxicity. In this regard, it has to be noted that the tumor cell lines selected for the study are MR-deficient and therefore represent a model of resistance to $\mathrm{O}^{6}$-methylating agents.

Inhibition of BER process, that is involved in the repair of adducts different from $\mathrm{O}^{6}$-methylguanine, has been recently demonstrated to represent a valuable strategy to sensitize MR-deficient tumor cells to methylating agents. ${ }^{20,22,23}$ In fact, even though $\mathrm{O}^{6}$-methylguanine has been, until now, the best studied cytotoxic DNA lesion, it is neither the most abundant nor the only adduct generated by these compounds. ${ }^{21}$ In the absence of MR function, interruption of BER-mediated repair process of $\mathrm{N}$-methyl-purine adducts, by means of PARP inhibition, might play a crucial role in the cytotoxicity induced by TZM.

Treatment with TZM+PARP inhibitor of MR-deficient leukemic or colon cancer cells, bearing wild-type p53, is followed by the induction of p53 and p21 proteins ( $L$ Tentori and G Graziani, unpublished observation). These observa- 

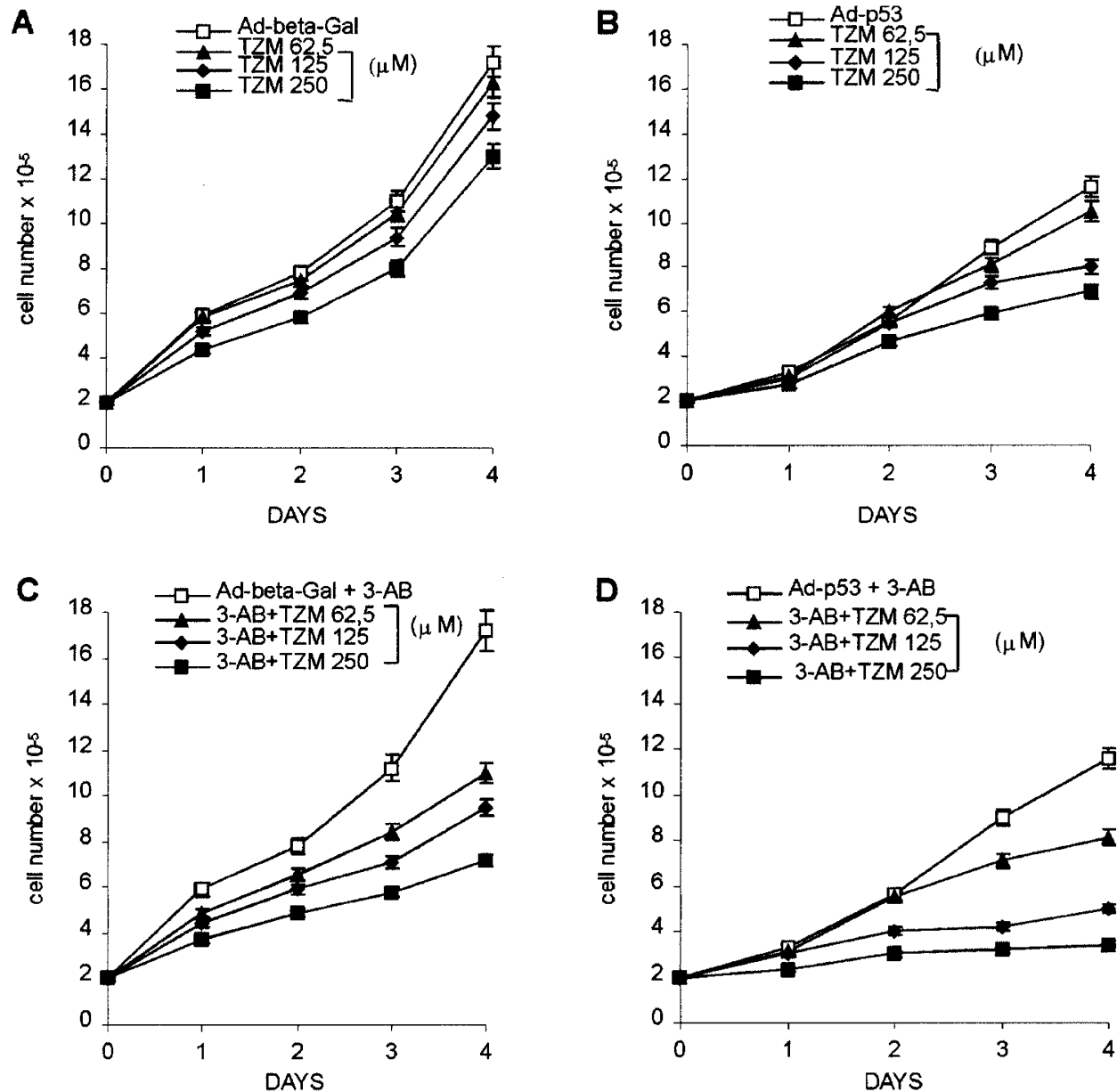

Figure 11 Cell growth analysis of MT-1 cells treated with TZM, as a single agent (A, B) or combined with 3-AB (C, D), after infection with either Ad-beta-Gal (A, C) or Ad-p53 (B, D). The experiment was repeated once with comparable results. Statistically significant differences between groups are reported in the Results section

tions suggested that the DNA damage deriving from interruption of the repair of $\mathrm{N}$-methyl-purine adducts triggers the p53-dependent machinery. The results of the present study indicated that Ad-p53 infection markedly enhanced tumor cell susceptibility to the combination of the methylating agent TZM with a PARP inhibitor. In particular, when Ad-p53 infected tumor cells were exposed to the drug combination, they were no longer able to proliferate and accumulated in the $\mathrm{G}_{1}$ phase of cell cycle. Interestingly, in the case of HCT-15 line, cells were extremely sensitive to growth inhibition provoked by ectopic expression of p53. Therefore, potentiation of drug-mediated cytotoxicity was particularly evident when cells were infected at $\mathrm{MOI}$ concentrations (2.5 and $20 \mathrm{MOI})$ devoid of cytotoxic effects.

It is worth noting that overexpression of p53 enhanced also the susceptibility of MR-deficient cells to the treatment with TZM used as single agent. It can be speculated that in experimental conditions of high levels of p53 expression, the repair of adducts different from $\mathrm{O}^{6}$-methylguanine might be impaired.

The observation that, in tumor cells bearing an intact p53 gene, drug treatment induced growth arrest only when cells were previously infected with Ad-p53, suggests that Ad-p53 infection does not represent a mere replacement of wildtype function. It can be speculated that the presence of high levels of p53 protein, before exposure to the drugs, might sensitize cells to DNA damage and promote apoptosis.

The clinical interest in methylating agents, such as dacarbazine or TZM, is related to their activity against tumors of different origin. Dacarbazine is the drug of choice for the treatment of melanoma, and is also used for the treatment of sarcomas and lymphomas. In addition, it has shown activity in acute leukemias, relapsed or refractory to standard chemotherapy. ${ }^{35}$ Of interest, phase II and III trials demonstrated that TZM is effective against recurrent glioma, and melanoma. ${ }^{36-39}$

Although promising, the antitumor activity of methylating agents is far from being resolved. Poor responsiveness of solid tumors to cancer chemotherapy is mainly related to the fact that most of the cells are in a plateau growth phase, with only a small fraction of actively proliferating cells. Moreover, it has been shown that, in some cases, Adp53 infection did not result in enhanced lethal effect of the 

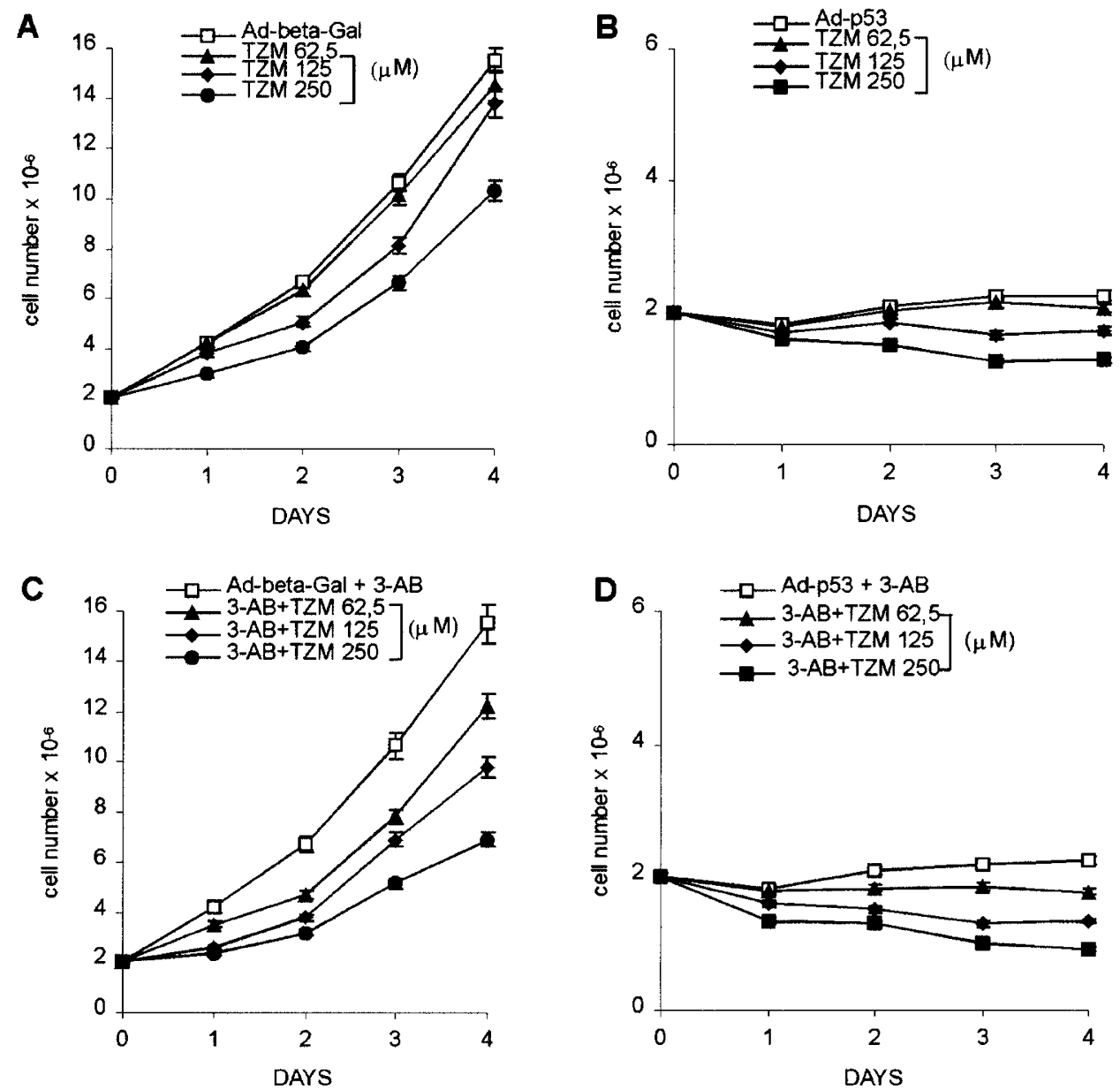

Figure 12 Cell growth analysis of HCT-116 cells treated with TZM, as a single agent (A, B) or combined with 3-AB (C, D), after infection with either Ad-beta-Gal $(A, C)$ or Ad-p53 (B, D). The experiment was repeated once with comparable results. Statistically significant differences between groups are reported in the Results section

antitumor agent, when cells were exposed to the drug after infection. In fact, in the case of chloroethylating agents, tumor cells were less susceptible to the sequence Ad-p53 $\rightarrow$ drug than to the reverse sequence, which instead induced a marked growth inhibitory effect. ${ }^{40}$ These observations were related to the fact that p53 overexpression would induce $G_{1}$ arrest, thus hampering the DNA damage induced by alkylating agents that require DNA synthesis in order to cause cell death. Moreover, p53 overexpression, when achieved before drug treatment, did not result in increased cell susceptibility to other antineoplastic agents such as the mitosis specific agent taxol. ${ }^{41}$ On the basis of these observations, it has been investigated whether MR-deficient and non-proliferating p53 expressing cells could still be sensitized to the treatment with TZM, used as single agent or in combination with PARP inhibitor. The results of the present study indicated that the drug combination of TZM and PARP inhibitor was still highly effective, even in the absence of DNA synthesis. Thus, it is conceivable that cytotoxicity deriving from interruption of the repair of adducts different from $\mathrm{O}^{6}$. methylguanine does not require cell proliferation. In contrast, cytotoxicity deriving from the processing of $0^{6}$ methylguanine, in MR-proficient cells, occurs only during the second cycle of DNA replication, that follows adduct generation. ${ }^{18}$

When growth arrested cells were exposed to TS inhibitor, this agent lost the ability to kill tumor cells. In this case, lack of antitumor activity might be attributed to the fact that only cells that actively synthesize DNA can be damaged upon reduction of the availability of thymidilic nucleotides. In contrast, 5-FU, that either acts as an indirect inhibitor of TS or affects RNA functions, was still active in non-proliferating cells. Actually, wild-type p53 expression increased 5-FU cytotoxic activity, in accordance with previous studies performed using different model systems. ${ }^{41-43}$

At present, adenovirus-mediated p53 gene therapy for cancer is currently undergoing phase $1 / / \mathrm{ll}$ clinical trials. These studies are being conducted with the aim of utilizing Ad-p53, by intratumoral injection, as a surgical adjuvant in patients with advanced head and neck cancer ${ }^{44}$ and nonsmall-cell lung carcinoma. ${ }^{45}$ Moreover, Ad-p53 has also been delivered by intrahepatic artery route of administration 
for the treatment of liver metastasis of colorectal cancer. ${ }^{46}$ However, the results of the present study raise some concerns on the use of Ad-p53 as single agent, taking into account that adenovirus infection might not be targeted to the whole cell population or result in persistent growth arrest. In addition, a number of preclinical studies suggested that Ad-p53 gene therapy should be combined to chemotherapy or radiotherapy, because enhanced antitumor activity has been observed in different model systems. $^{25,27,41,42,47}$

In conclusion the results of the present study propose a future strategy based on Ad-p53 infection in combination with either TZM or TZM+PARP inhibitor, especially in the case of drug resistant tumors.

\section{Materials and Methods}

\section{Cells and cell culture}

All cell lines were purchased from the American Type Culture Collection (ATCC, Rockville, MD, USA), with the exception of the human lymphoblastoid MT- $1,{ }^{48}$ that was a generous gift from WG Thilly (Massachusetts Institute of Technology, Cambridge, MA, USA). The T-lymphoblastic leukemia Jurkat cell line is p53-null, ${ }^{49}$ whereas MT-1 is capable of inducing p53 upon treatment with DNA damaging agents. $^{18}$

The colon carcinoma HCT-15 cell line expresses a mutated form of p53 $3^{50}$ whereas HCT-116 possesses a wild-type form of p53. ${ }^{51}$

All cell lines listed above are MR-deficient. ${ }^{48,52-55}$

The lymphoblast-like Raji and the colon carcinoma HT-29 cell lines, both expressing a mutated form of $p 53,{ }^{56,57}$ were used as controls in Western blot analysis. Cells were cultured at $37^{\circ} \mathrm{C}$ in a $5 \% \mathrm{CO}_{2}$ humidified atmosphere in RPMI-1640 (Gibco, Paisley, Scotland, UK), supplemented with $10 \%$ heat inactivated $\left(56^{\circ} \mathrm{C}, 30 \mathrm{~min}\right)$ fetal calf serum (Gibco), 2 mM L-glutamine, and antibiotics (Flow Laboratories, McLean, VA, USA).

\section{Drugs}

TZM was kindly provided by Schering-Plough Research Institute (Kenilworth, NJ, USA). The thymidylate synthase inhibitor $\mathrm{N}-[5-[\mathrm{N}-$ (3,4-dihydro-2-methyl-4-oxoquinazolin-6-ylmethyl)- $N$-methylamino]-2thenoyl]-L-glutamic acid (raltitrexed), was a kind gift of Dr. K Lu (Roswell Park Cancer Institute, Buffalo, NY, USA). The PARP inhibitor $3-A B$ was purchased from Sigma-Aldrich (Milan, Italy). The antimetabolite 5 -FU was purchased by Roche (Milan, Italy). Drug stock solutions were prepared by dissolving TZM and raltitrexed in dimethyl sulfoxide, $3-A B$ and $5-F U$ in RPMI-1640. The final concentration of dimethyl sulfoxide was always less than $0.1 \%(\mathrm{v} / \mathrm{v})$ and did not contribute to toxicity (data not shown).

\section{Adenovirus vectors and infection}

For this study two replication-deficient, recombinant adenovirus vectors were used. AdCMV.p53 (Ad-p53), ${ }^{33}$ that contains the human wild-type p53 cDNA driven by the CMV promoter, was a generous gift from Dr. B Vogelstein (Johns Hopkins University, Baltimore, MD, USA). As a control vector, AdCMV.NLS beta-Gal (Ad-beta-Gal), that expresses the beta-galactosidase gene, was used. ${ }^{33}$ This vector, that expresses nuclear localized beta-galactosidase, was obtained from Dr. MC Capogrossi ('Istituto Dermopatico dell'Immacolata', Rome,
Italy). The virus titers were determined by plaque formation following infection of human primary embryonal cells of kidney 293 line. MOI was defined as the ratio of the total number of plaque-forming units used in a particular infection per total number of cells to be infected. Jurkat and HCT-15 cells were infected with Ad equivalent to a $\mathrm{MOI}$ of $2.5,20$ or 80 , as specified. Tumor cells, in the exponential phase of growth, were infected, by adding Ad in $1 \mathrm{ml}$ RPMI per $1 \times 10^{6}$ cells. After $1 \mathrm{~h}$, the medium was replaced with fresh medium and cells were cultured at the concentration of $2 \times 10^{5}$ cells $/ \mathrm{ml}$ for an additional 4 days. At daily intervals, cells were counted and collected for flow cytometry or Western-blot analysis.

\section{Drug treatment and cell growth evaluation}

Drug treatment was performed 1 day after Ad exposure. In selected experiments with HCT-15 line, cells were exposed to the drugs 2 days after infection at a $\mathrm{MOI}$ of 20 . Cells were seeded in culture flasks (Falcon, Becton \& Dickinson Labware, Oxnard, CA, USA) at the a concentration of $2 \times 10^{5}$ cells $/ \mathrm{ml}$. TZM was added to the culture medium at final concentrations ranging between 62.5 and $250 \mu \mathrm{M}$. Inhibition of PARP was obtained by treating the cells with $4 \mathrm{mM} 3-\mathrm{AB}$, a concentration that has been described as abrogating PARP activity. ${ }^{58}$ The PARP inhibitor was added to the cultures immediately before TZM treatment. Cells were then incubated at $37^{\circ} \mathrm{C}$ for 4 days and cell growth was evaluated in terms of count of viable cells, every $24 \mathrm{~h}$. Cells were manually counted in quadruplicate using a haemocytometer, and cell visibility was determined by trypan blue exclusion test.

\section{Statistical analysis}

The results are presented as mean values of quadruplicate counts \pm standard error (S.E.). In the case of percentage values, means and the relative S.E. were calculated following angular transformation of the data. Statistical analysis was performed by Student's $t$-test.

\section{Western blotting}

Cell lysates and samples for electrophoresis were prepared as previously described. ${ }^{20}$ Eighty $\mu \mathrm{g}$ of protein per sample were electrophoresed in 12\% SDS-polyacrylamide mini-gels. Afterwards, proteins were transferred to nitrocellulose membranes (Schleicher \& Schuell, Keene, NH). Equal protein loading was visualized by Ponceau $S$ staining. Filters were blocked with blocking buffer (Boehringer Mannheim) and incubated with monoclonal antibodies directed against p53 (clone PAb1801), p21 WAF1/CIP1 (p21, clone EA10) (Oncogene, Cambridge, MA, USA) or with antibody against actin (Sigma). Immunecomplexes were visualized using a chemiluminescence kit (Amersham International PIc, Amersham, UK), according to the manufacturer's instructions. Filters were exposed to X-OMAT AR autoradiographic films (Kodak, Rochester, NY, USA) for 10-45 s, depending on the intensity of the signal. Bidimensional densitometry of the blots was performed using an imaging densitometer, GS-670 (BioRad, Richmond, CA, USA) and optical densities (O.D.) were expressed as arbitrary units.

\section{Cell fractionation}

Cells were swollen in hypotonic buffer containing $10 \mathrm{mM}$ Tris $\mathrm{HCl} \mathrm{pH}$ 7.5, $1.5 \mathrm{mM} \mathrm{MgCl} 2,10 \mathrm{mM} \mathrm{KCl}, 0.5 \mathrm{mM}$ dithiothreitol, aprotinin, leupeptin, soybean trypsin inhibitor, 4-(2-aminoethyl)-benzene-sulfo- 
nyl fluoride hydrochloride and disrupted by 30 strokes in a tight fitting dounce homogenizer until nuclei were released as observed by phase microscopy. After low speed centrifugation $(600 \times g)$, the nuclear fraction was collected and the supernatant, corresponding to the soluble and particulate fractions of the cytoplasm, was lysed using $1 \times$ buffer (50 mM Tris $\mathrm{HCl}$ pH 7.5, 2 mM EGTA, $10 \mathrm{mM}$ dithiothreitol, 1\% Triton X-100 or $4 \times$, buffer, respectively.

\section{Assessment of apoptosis and cell cycle analysis}

Cells from cultures were washed with PBS and fixed in $70 \%$ ethanol at $-20^{\circ} \mathrm{C}$ for $18 \mathrm{~h}$. The centrifuged pellets were resuspended in $1 \mathrm{ml}$ of hyptotonic solution containing propidium iodide (PI) $(50 \mu \mathrm{g} / \mathrm{ml}), 0.1 \%$ sodium citrate, $0.1 \%$ Triton-X, and RNase $(10 \mu \mathrm{g} / \mathrm{ml})$ (PI solution). Cells were incubated in the dark, at $37^{\circ} \mathrm{C}$ for $15 \mathrm{~min}$. Data collection was gated utilizing forward light scatter and side light scatter to exclude cell debris and cell aggregates. The PI fluorescence was measured on a linear scale using a FACSscan flow cytometer (Becton and Dickinson, San Jose, CA, USA). Apoptotic cells, are represented by a broad hypodiploid peak (sub-G1), which is easily distinguishable from the narrow peak of cells with diploid DNA content in the red fluorescence channel. All data were recorded and analyzed using Lysis II software. For cell cycle analysis the cell-fit software was used (Becton and Dickinson).

Apoptosis was always confirmed by morphological analysis of nuclear fragmentation of cells fixed with methanol/acetic acid (3/1) and then stained with $5 \%$ Giemsa in phosphate buffer. The results of morphological analysis were always comparable to those obtained by flow cytometry (data not shown).

\section{Evaluation of 5-BrdU incorporation}

Ad-beta-Gal and Ad-p53 infected cells were cultured for 2 days and pulsed with $10 \mu \mathrm{M} 5-\mathrm{BrdU}$ (Sigma) $1 \mathrm{~h}$ before harvesting. Ethanol fixed cells were washed with PBS, resuspended in $2 \mathrm{ml}$ of $2 \mathrm{M} \mathrm{HCl}$, and incubated at room temperature for $30 \mathrm{~min}$. Cells were then centrifuged, resuspended in $2 \mathrm{ml}$ of $0.1 \mathrm{M} \mathrm{Na}_{2} \mathrm{~B}_{4} \mathrm{O}_{7}, \mathrm{pH} 8.5$ (to neutralize acidity) and washed with PBS containing $0.5 \%(\mathrm{v} / \mathrm{v})$ Tween 20 and $1 \%(\mathrm{w} / \mathrm{v})$ bovine serum albumine. The cell pellets were resuspended in $0.1 \mathrm{ml}$ of PBS containing $0.4 \mathrm{mg}$ of anti-5-BrdU (Boehringer Mannheim, Mannheim, Germany) and were maintained at room temperature in the dark for $30 \mathrm{~min}$. They were then washed and stained with $0.1 \mathrm{ml}$ of diluted (1/50) FITC-labeled (Fab')2 rabbit antimouse IgG $(\mathrm{H}+\mathrm{L}$ chains) (Dako, Glostrup, Denmark). Negative controls were represented by cell samples stained with FITC-labeled rabbit anti-mouse IgG only. After $30 \mathrm{~min}$ incubation, cells were washed, resuspended in $1 \mathrm{ml}$ of $\mathrm{PI}$ solution and then incubated at $37^{\circ} \mathrm{C}$ for $10 \mathrm{~min}$. Cell samples were analyzed for green (FITC, indicating $5-\mathrm{BrdU}$ incorporation) and red ( $\mathrm{PI}$, indicating DNA content) fluorescence, using a FACScan flow cytometer. The number of cells in each phase of cell cycle was analyzed using the Lysis II software. The results were displayed as representative two-dimensional frequency dot plots of green versus red fluorescence.

\section{Acknowledgments}

This study was supported by a grant from the Italian Association for Cancer Research (AIRC) and by MURST (Molecular bases for the pharmacological control of neoplastic diseases). The authors would like to thank Dr. A Bergamini (University of Rome 'Tor Vergata') for suggestions on Ad infection and C Mastrilli and G Bonelli for their excellent technical assistance.

\section{References}

1. Hartwell LH and Kastan MB (1994) Cell cycle control and cancer. Science 266: $1821-1828$

2. Kastan MB, Canman CE and Leonard CJ (1995) p53, cell cycle control and apoptosis: implications for cancer. Cancer Metastasis Rev. 14: 3-15

3. Levine AJ (1997) p53, the cellular gate-keeper for growth and division. Cell 88: $323-331$

4. Lowe S, Bodis S, McClatchey A, Remington L, Ruley HE, Fisher DE, Housman DE and Jacks T (1994) p53 status and the efficacy of cancer therapy in vivo. Science 266: $807-810$

5. Liu TJ, el-Naggar AK, McDonnell TJ, Steck KD, Wang M, Taylor DL and Clayman GL (1995) Apoptosis induction mediated by wild-type p53 adenoviral gene transfer in squamous cell carcinoma of the head and neck. Cancer Res. 55: 3117-3122

6. Gomez-Manzano C, Fueyo J, Kyritsis AP, Steck PA, Roth JA, McDonnel TJ, Steck KD, Levin VA and Yung WK (1996) Adenovirus-mediated transfer of the p53 gene produces rapid and generalized death of human glioma cells via apoptosis. Cancer Res. 56: 694-699

7. Liu TJ, Zhang WW, Taylor DL, Roth JA, Goepfert H and Clayman GL (1994) Growth suppression of human head and neck cancer cells by the introduction of a wild-type p53 gene via a recombinant adenovirus. Cancer Res. 54: 3662-3667

8. Harris MP, Sutjipto S, Wills KN, Hancock W, Cornell D, Johnson DE, Gregory RJ, Shepard HM and Maneval DC (1996) Adenovirus-mediated p53 gene transfer inhibits growth of human tumor cells expressing mutant p53 protein. Cancer Gene Ther. 3: $121-130$

9. Nielsen LL and Maneval DC (1998) p53 tumor suppressor gene therapy for cancer. Cancer Gene Ther. 5: 52-63

10. Levine AJ, Momand J and Finlay CA (1991) The p53 tumour suppressor gene. Nature 351: $453-456$

11. Baker SJ, Fearon ER, Nigro JM, Hamilton S, Preisinger AC, Jessup JM, vanTuinen $\mathrm{P}$, Ledbetter DH, Barker DF, Nakamura Y, White R and Vogelstein B (1989) Chromosome 17 deletions and p53 gene mutations in colorectal carcinomas. Science 244: 217-221

12. Ben-Yehuda D, Krichevsky S, Caspi O, RundD, PolliackA, AbeliovichD, Zelig O, Yahalom V, Paltiel O, OrR, Peretz T, Ben-Neriah S, Yehuda O and Rachmilewitz EA (1996) Microsatellite instability and p53 mutations in therapy related leukemia suggest a mutator phenotype. Blood 88: 4296-4303

13. Zhu YM, Das-Gupta EP and Russell NH (1999) Microsatellite instability and p53 mutations are associated with abnormal expression of the MSH2 gene in adult acute leukemia. Blood 94: 733-740

14. Wattel E, Preudhomme C, Hecquet B, Vanrumbeke M, Quesnel B, Dervite I, Morel P and Fenaux P (1994) p53 mutations are associated with resistance to chemotherapy and short survival in hematologic malignancies. Blood 84: 3148 3157

15. Zhu YM, Foroni L, McQuacker IG, Papaioannou M, Haynes A and Russel HH (1999) Mechanisms of relapse in acute leukemia: Involvement of p53 mutated subclones in disease progression in acute lymphoblastic leukaemia. Br. J. Cancer 79: 1151-1157

16. Jiricny J (1998) Eukaryotic mismatch repair: an update. Mutat. Res. 409: $107-$ 121

17. Fink D, Aebi S and Howell SB (1998) The role of DNA mismatch repair in drug resistance. Clin. Cancer Res. 4: 1-6

18. D’Atri S, Tentori L, Lacal PM, Graziani G, Pagani E, Benincasa E, Zambruno G, Bonmassar E and Jiricny J (1998) Involvement of the mismatch repair system in temozolomide-induced apoptosis. Mol. Pharmacol. 54: 334-341

19. Tentori L, Lacal PM, Benincasa E, Franco D, Faraoni I, Bonmassar E and Graziani G (1998) Role of wild-type p53 on the antineoplastic activity of temozolomide alone or combined with inhibitors of poly(ADP-ribose) polymerase. J. Pharmacol. Exp. Ther. 285: 884-893

20. Tentori L, Turriziani M, Franco D, Serafino A, Levati L, Roy R, Bonmassar E and Graziani G (1999) Treatment with temozolomide and poly(ADP-ribose) polymerase inhibitors induces early apoptosis and increases base excision repair gene transcripts in leukemic cells resistant to triazene compounds. Leukemia 13: $901-909$

21. Newlands ES, Stevens MF, Wedge SR, Wheelhouse RT and Brock C (1997) Temozolomide: a review of its discovery, chemical properties, pre-clinical development and clinical trials. Cancer Treat. Rev. 23: 35-61 
22. Wedge SR, Porteous JK and Newlands ES (1996) 3-aminobenzamide and/or $0^{6}$-benzylguanine evaluated as an adjuvant to temozolomide or BCNU treatment in cell lines of variable mismatch repair status and $\mathrm{O}^{6}$-alkylguanineDNA alkkyltransferase activity. Br. J. Cancer 74: 1030-1036

23. Liu L, Taverna P, Whitacre CM, Chatterjee S and Gerson SL (1999) Pharmacologic disruption of base excision repair sensitizes mismatch repairdeficient and -proficient colon cancer cells to methylating agents. Clin. Cancer Res. 5: $2908-2917$

24. Wilson III DM and Thompson LH (1997) Life withoutDNA repair. Proc. Natl. Acad. Sci. USA 94: $12754-12757$

25. Fujiwara T, Grimm EA, Mukhopadhyay T, Zhang WW, Owen-Shaub LB and Roth JA (1994) Induction of chemosensitivity in human lung cancer cells in vivo by adenovirus-mediated transfer of the wild-type p53 gene. CancerRes. 54:22872291

26. Katayose D, Gudas J, Nguyen H, Srivastava S, Cowan KH and Seth P (1995) Cytotoxic effects of adenovirus-mediated wild-type p53 protein expression in normal and tumor mammary epithelial cells. Clin. Cancer Res. 1: 889-897

27. Ogawa N, Fujiwara T, Kagawa S, Nishizaki M, Morimoto Y, Tanida Y, Hizuta A, Yasuda T, Roth JA and Tanaka N (1997) Novel combination therapy for human colon cancer with adenovirus-mediated wild-type p53 gene transfer and DNAdamaging chemotherapeutic agent. Int. J. Cancer 73: 367-370

28. Cirielli C, Riccioni T, Yang C, Pili R, Gloe T, Chang J, Inyaku K, Passaniti A and Capogrossi MC (1995) Adenovirus-mediated gene transfer of wild-type p53 results in melanoma cell apoptosis in vitro and in vivo. Int. J. Cancer 63:673-679

29. Li H, Lochmuller H, Yong VW, Tarpati G and Nalbantoglu J (1997) Adenovirusmediated wild-type p53 gene transfer and overexpression induces apoptosis of human glioma cells independent of endogenous p53 status. J. Neuropathol. Exp. Neurol. 56: 872-878

30. Fujiwara T, Grimm EA, Mukhopadhyay T, Cai DW, Owen-Schaub LB and Roth JA (1993) A retroviral wild-type p53 expression vector penetrates human lung cancer spheroids and inhibits growth by inducing apoptosis. Cancer Res. 53: 4129-4133

31. Blagosklonny MV and el-Deiry WS (1996) In vitro evaluation of a p53-expressing adenovirus as an anti-cancer drug. Int. J. Cancer 67: 386-392

32. Wattel E, Vanrumbeke M, Abina MA, Cambier N, Preudhomme C, Haddada H and Fenaux P (1996) Differential efficacy of adenoviral mediated gene transfer into cells from hematological cell lines and fresh hematological malignancies. Leukemia 10: 171-174

33. el-Deiry WS, Tokino T, Velculescu VE, Levy DB, Parsons R, Trent JM, Lin D, Mercer WE, Kinzler KW and Vogelstein B (1993) WAF1, a potential mediator of p53 tumor suppression. Cell 75: 817-825

34. el-Deiry WS, Harper JW, O'Connor PM, Velculescu VE, Canman CE, Jackman J, Pietenpol JA, Burrell M, Hill DE, Wang Y, Wiman KG, Mercher WE, Kastan MB, Kohn KW, Elledge SJ, Kinzler KW and Vogelstein B (1994) WAF1/CIP1 is induced in p53-mediated G1 arrest and apoptosis. Cancer Res. 54: 1169-1174

35. Franchi A, Papa G, D'Atri S, Piccioni D, Masi M and Bonmassar E (1992) Cytotoxic effects of dacarbazine in patients with acute myelogenous leukemia: $a$ pilot study. Haematologica 77: 146-150

36. Bower M, Newlands ES, Bleehen NM, Brada M, Begent RJ, Calvert H, Colquhoun I, Lewis P and Brampton MH (1997) Multicentre CRC phase II trial of temozolomide in recurrent or progressive high-grade glioma. Cancer Chemother. Pharmacol. 40: 484-488

37. Yung WK, Prados MD, Yaya-Tur R, Rosenfeld SS, Brada M, Friedman HS, Albright R, Olson J, Chang SM, O'Neill AM, Friedman AH, Bruner J, Yue N, Dungan M, Zaknoen S and Levin VA (1999) Multicenter phase II trial of temozolomide in patients with anaplastic astrocytoma or anaplastic oligoastrycytoma at first relapse: Temodal Brain Tumor Group. J. Clin. Oncol. 17:27622771

38. Bleehen NM, Newlands ES, Lee SM, ThatcherN, Selby P, CalvertAH, Rustin GJ, Brampton M and Stevens MF (1995) Cancer Research Campaign phase II trial of temozolomode in metastatic melanoma. J. Clin. Oncol. 13: 910-913

39. Middleton MR, Grob JJ, Aaronson N, Fierlbeck G, Tilgen W, Seiter S, Gore M, Aamdal S, Cebon J, Coates A, Dreno B, Henz M, Schadendorf D, Kapp A, Weiss J, Fraass U, Statkevich P, Muller M and Thatcher N (2000) Randomized phase III study of temozolomide versus dacarbazine in the treatment of patients with advanced metastatic malignant melanoma. J. Clin. Oncol. 18: 158-166

40. Biroccio A, Bufalo DD, Ricca A, D'Angelo C, D'Orazi G, Sacchi A, Soddu S and Zupi G (1999) Increase of BCNU sensitivity by wt-p53 gene therapy in glioblastoma lines depends on the administration schedule. Gene Ther. 6: 1064-1072
41. Blagosklonny MV and el-Deiry WS (1998) Acute overexpression of WT p53 facilitates anticancer drug-induced death of cancer and normal cells. Int. J. Cancer 75: 933-940

42. Yang B, Eshleman JR, Berger NA, Markowitz SD (1996) Wild-type p53 protein potentiates cytotoxicity of therapeutic agents in human colon cancer cells. Clin. Cancer Res. 2: 1649-1657

43. Gurnani M, Lipari P, Dell J, Shi B and Nielsen LL (1999) Adenovirus-mediated p53 gene therapy has greater efficacy when combined with chemotherapy against human head and neck, ovarian prostate and breast cancer. Cancer Chemother. Pharmacol. 44: 143-151

44. Clayman GL, Frank DK, Bruso PA and Goepfert H (1999) Adenovirus-mediated wild-type p53 gene transfer as a surgical adjuvant in advanced head and neck cancers. Clin. Cancer Res. 5: 1715-1722

45. Swisher SG, Roth JA, Nemunaitis J, Lawrence DD, Kemp BL, Carrasco CH, Connors DG, El-Naggar AK, Fossella F, Glisson BS, Hong WK, Khuri FR, Kurie JM, Lee JJ, Lee JS, Mack M, Merritt JA, Nguyen DM, Nesbitt JC, Perez-Soler R, Pisters KMW, Putnam Jr JB, Richli WR, Savin M, Schrump DS, Shin DM, Shulkin A, Walsh GL, Wait J, Weill D and Waugh MKA (1999) Adenovirus-mediated p53 gene transfer in advanced non-small-cell lung cancer. J. Natl. Cancer Inst. 91: $763-771$

46. Habib NA, Hodgson HJ, Lemoine N and Pignatelli M (1999) A phase I//I study of hepatic artery infusion with wtp53-CMV-Ad in metastatic malignant liver tumours. Hum. Gene Ther. 10: 2019-2034

47. Pirollo KF, Hao Z, Rait A, Jang YJ, Fee Jr WE, Ryan P, Chiang Y and Chang EH (1997) p53-mediated sensitization of squamous cell carcinoma of the head and neck to radiotherapy. Oncogene 14: 1735-1746

48. Kat A, Thilly WG, Fang WH, Longley MJ, Li GM and Modrich P (1993) An alkylation-tolerant, mutator human cell line is deficient in strand-specific mismatch repair. Proc. Natl. Acad. Sci. USA 90: 6424-6428

49. Iwamoto KS, Mizuno T, Ito T, Tsuyama N, Kyoizumi Sand Seyama T(1996) Gainof-function p53 mutations enhance alteration of the T-cell receptor following $X$ irradiation, independently of the cell cycle and cell survival. Cancer Res. 56 : $3862-3865$

50. Shibata D, Peinado MA, Ionov Y, Malkhosyan S and Perucho M (1994) Genomic instability in repeated sequences is an early somatic event in colorectal tumorigenesis that persists after transformation. Nat. Genet. 6: 273-281

51. Take Y, Kumano M, Teraoka H, Nishimura S, Okuyama (1996) A DNAdependent protein kinase inhibitor (OK-1035) suppresses p21 expression in HCT116 cells containing wild-type p53 induced by adriamycin. Biochem. Biophys. Res. Commun. 221: 207-212

52. Levati L, Marra G, Lettieri T, D’Atri S, Vernole P, Tentori L, Lacal PM, Pagani E, Bonmassar E, Jiricny J and Graziani G (1998) Mutation of the mismatch repair gene $\mathrm{hMSH} 2$ and $\mathrm{hMSH} 6$ in a human T-cell leukemic line tolerant to methylating agents. Genes Chromosome Cancer 3: 159-166

53. da Costa LT, Liu B, el-Deiry W, Hamilton SR, Kinzler KW, Vogelstein B, Markowitz S, Willson JK, de la Chapelle A, Downey KM and So AG (1995) Polymerase delta variants in RER colorectal tumors. Nat. Genet. 9: 10-11

54. Papadopoulos N, Nicolaides NC, Wei YF, Ruben SM, Carter KC, Rosen CA, Haseltine WA, Fleischmann RD, Fraser CM, Adams MD, Venter JC, Hamilton SR, Petersen GM, Watson P, Lynch HT, PeltomakiP, Mecklin J-P, de le Chapelle A, Kinzler KW and Vogelstein B (1994) Mutation of a mutL homologue in hereditary colon cancer. Science 263: 1625-1629

55. Parsons R, Li GM, Longley MJ, Fang WH, Papadopoulos N, Jen J, de la Chapelle A, Kinzler KW, Vogelstein B and Modrich P (1993) Hypermutability and mismatch repair deficiency in RER+ tumor cells. Cell 75: 1227-1236

56. Duthu A, Debuire B, Romano J, Ehrhart JC, Fiscella M, May E, Appella Eand May P (1992) p53 mutations in Raji cells: characterization and localization relative to other Burkitt's lymphomas. Oncogene 7: 2161-2167

57. Nagasawa H, Li CY, Maki CG, Imrich AC and Little JB (1995) Relationship between radiation-induced $\mathrm{G}_{1}$ phase arrest and $\mathrm{p} 53$ function in human tumo cells. Cancer Res. 55: 1842-1846

58. Boulton S, Pemberton LC, Porteous JK, Curtin NJ, Griffin RJ, Golding BT and Durkacz BW (1995) Potentiation of temozolomide-induced cytotoxicity: a comparative study of the biological effects of poly(ADP-ribose) polymerase inhibitors. Br. J. Cancer 72: 849-856 